\title{
Experiencing the effect of demonetization on service sectors in India
}

\author{
R. Seranmadevi ${ }^{\mathrm{a}}$ and A. Senthil Kumar ${ }^{\mathrm{a}^{*}}$
}

${ }^{a}$ School of Commerce Studies, Jain (Deemed-to-be) University, Bengaluru, Karnataka, India

\begin{tabular}{l}
\hline C H R O N I C L E \\
\hline Article history: \\
Received: October 7, 2018 \\
Received in revised format: No- \\
vember 29, 2018 \\
Accepted: December 16, 2018 \\
Available online: \\
December 18, 2018 \\
\hline Keywords: \\
Demonetization \\
Service sector \\
Effect \\
Impact \\
Preventing corruption \\
Black money
\end{tabular}

\section{A B S T R A C T}

\begin{abstract}
Like freedom of India, the demonetization reform was also unveiled in India during the midnight by the Indian Government and it was declared that one thousand and five hundred rupee notes would no longer be legal tender effective from 8th November 2016. At the same time, the Reserve Bank of India issued new two thousand rupee notes and new five hundred rupee notes on November, 10, 2016. This initiative was taken by the Central Government with the aim of preventing corruption, reducing black money and counterfeit currency notes. There was a significant impact on the entire Indian economy system and it was urged the citizens to switch to alternative modes of payment due to non-availability of hot currency i.e., e-payments, hence people faced many problems in all transactions after demonetization especially in service sectors. This paper performs a questionnaire based survey by collecting the necessary data from 629 beneficiaries/customers of service sector organisations in Chennai, the capital of Tamil Nadu state, India during NovemberDecember 2017 to measure the effects of demonetization after a year. Confirmatory Factor Analysis (Structural Equations Model) was used to analyse the relationship between the effect, sustainability and the impact on the customer satisfaction. The study found that demonetization based on Adoptability, Implementation, Readiness and Acceptance of new payment methods significantly influenced the customer satisfaction under service sector. The effects of different factors such as Approach, Availability, Time, Delivery and Infrastructure also had significant contribution towards the customers' satisfaction.
\end{abstract}

\section{Introduction}

Demonetization is the act of transforming the existing currency in different form. It can also mean that replacing the old currency with new currency or launching new coins or notes of the same currency. In India, demonetization reforms were already taken by the Central Government during 1946, 1956 and 1978 for curbing the black money and counterfeit money. In 2016, Indian Prime Minister Shri Narendra Modi stated that all high value denominated 500 and 1,000 rupee notes would have been ceased to become legal tender. The objectives of this demonetization were (a) to curb the menace of fake currencies; (b) to destroy unaccounted and tax evaded money stored in high-value notes; and (c) to prevent use of high denomination notes for terror financing. During pre-demonetization, around 86 per cent of the currency in circulation and 95 per cent of all transactions in India were executed in cash, 90 per cent of vendors had no alternatives to accept anything for cash, 85 per cent of workers in all fields were

* Corresponding author. Tel.: +91 9842922937

E-mail address: senthilvisangm@gmail.com (A. Senthil Kumar) 
paid exclusively in cash and almost half of the population did not even have bank accounts (India Today, 2017). The action against the black money was appreciated by the majority of the people. However, few groups especially the corrupt politicians and businessmen protested and resisted the demonetization process. Indeed, the whole nation faced many troubles such as long queues in ATMs and Banks to withdraw a basic minimum amount of cash for few months. Especially the beneficiaries/customers of service sectors organisations and unorganised sectors affected many ways to face demonetisation towards cashless trade. Hence, it is necessary to study the effects of demonetization in the view point of services rendered by service sectors and this impact towards customer satisfaction.

\section{Review of Literature}

Many researchers have pointed out the importance of studying the impact and the effects of demonetization in India (Midthanpally, 2017; Uke, 2017; Shaikh \& Deshpande, 2017; Kaur, 2016). Chopra (2017) observed that the impact of demonetization on Gross Value Added growth was modest and negatively impacted the segments of manufacturing and service sector. Upadhyay and Suvarna (2018) conducted a study in pre and post demonetization announcement to analyse the impact of the announcement on its most important index in Indian Stock Market and indicated that there was no striking impact of the demonetization announcement on the stock returns during the period of the study. A study conducted by IndiaToday on November 9, 2017 in India said that 50 lakhs labourers got their bank accounts, terror incidents went down 45 per cent, imports rose by 23 per cent in a year, bank deposits rose, the black money was reduced and labourers in production industry got adversely affected. Currency ban adversely impacted the media and entertainment industry as it resulted in fewer number of viewers, Indian tourism industry especially local tourism, restaurant's businesses and the unorganised sectors are most impacted with the inability to make payment in cash (Kushwaha et al., 2018). Abolition of existing money stock that enables economic transactions is bound to have an economic impact and a loss of gross domestic product (Nag, 2016) and luxury hospitals saw some impact on the patients (Kumar \& Bumra, 2017). The impact of such a move would vary depending on the extent to which the government decides to remonetize and the impact on the availability of credit, spending, level of activity and government finances (Tax Research Team, 2016). There is a need for more structured data to establish demonetization as a specific stressor (Enara \& Mahesh, 2018).

\section{Statement of the Problem}

Digitalizing cash policy using online transactions or swipe their digital card for every smallest transactions will help in maintaining discipline and harmony among people and also prevent corruption. Aiming the above process created short-term problems among the working class especially daily wage labourers and the people who are dealing with cash on a daily basis. Also, the shortage of smaller denominator currency notes has created more chaos among all levels of people (Santani, 2018). The growth domestic product (GDP) growth rates of India for the financial year 2017 in four Quarter periods are 7.9, 7.5, 7 and 6.1, respectively. This was reduced to 5.7 in first quarter of Financial Year 2018 (The Bureau, The Economic Times, 2017). According to CMIE (Centre for Monitoring Indian Economy Pvt. Ltd.) report, the unorganised sectors have suffered job losses of 1.5 million during January to April 2017. The impact of demonetization has urged citizens to switch to alternative modes of payments such as pre-paid cards, credit and debit cards, mobile banking, and Internet banking (Special Correspondent, The Hindu, 2016). The impact of demonetization on growing middle class in India is very palpable. They are directly affected by the cash crunch, and it has seeped into all spheres of their lives (Enara \& Gowda, 2018). Demonetization has offered both challenges and opportunities in the digitization of the Indian economy (Kaur, 2016). The sudden reverse flow of cash from the purely cash economy to the formal banking sector would affect a huge flow in liquidity of regulated banking sector (Nag, 2016). The impact of demonetization was felt more in the social sector and the worst affected was also the poor and the common people. Without making law and discussion announcement of demonetization was made in the parliament (Inderjeet Santoshi, 2017). There is a significant impact on the 
Indian economy system after demonetization created a crash crunch in the economy where in every sector was effected (Adhikary \& Bora, 2017). Hence, it is necessary to analyze the impact, effects and customers satisfaction in service sector organisations after one year of demonetization in order to make suitable policy and regulatory actions towards it.

\section{Scope and Significance of the Study}

The study will find out the effects, impacts and sustainability of demonetization on performance of various service sectors in India after a whole year of experience of demonetization. Service sectors such as hospitals, hotels and restaurants, personal services (including dry cleaning, hair cutting and tax preparation), automobile services, legal services, social services, some agricultural services (including horticulture), transports, educational institutions, banks, insurance companies, entertainment sectors, tourism etc. and their customers were considered for the study. The study will help to find out the significant contributions made by the service sectors towards the customers' satisfaction after demonetization. Also it will help the statutory bodies and service sector organisations for better understanding about the effect of demonization and bring out different strategic decisions towards it.

\section{Objectives of the Study}

The present study focuses on studying the effects of demonetization and customers' satisfaction towards services rendered by various service sector organisations in Chennai, the capital of Tamil Nadu state, India after one year completion of demonetization. In order to find out the impact and the effect of demonetization, the objectives are framed:

1 To study the effects of demonetization in service sectors.

2 To evaluate the impact of demonetization procedure at the point of service delivery.

3 To analyze the customers' satisfaction under the parlance of sustainability in adoption of digital cash.

\section{Hypothesis}

The following null hypotheses are framed to find out the answers for the objectives of the study.

$\mathrm{H}_{1}$ : Effect of demonetization does not influence customer satisfaction.

$\mathrm{H}_{2}$ : Impact of demonetization does not influence the customer satisfaction.

$\mathrm{H}_{3}$ : Sustainability does not influence the customer satisfaction.

\section{Research Methodology}

\subsection{Participants and Data Collection}

In spite of the fact that a large number of service sector organisations exist in capital city of Tamil Nadu, the researchers have selected only few service sector organisations where there is a huge customer traffic, viz-a-viz different categories of customers/beneficiaries accessing their services more in number such as hospitals, transports, banks, entertainment areas, hotel and tourisms and educational institutions. The study was conducted during November-December 2017 after a whole year of completion of demonetization. The population includes the beneficiaries of service sector organisations covering all levels of people. The data required for the study is primary in nature. It is collected through a well framed questionnaire. The questionnaire contained items asking about their demographics, services provided by the different service sectors and various statements pertaining to demonetization. A pilot study was conducted with 15 beneficiaries who belong to Chennai city. Based on the feedbacks and discussions with the academic experts, the questionnaire was restructured. Next, 700 questionnaires were distributed among the customers of different service sectors by employing convenience sampling 
method. The data for the questionnaire were collected through offline as well as online mode using Google forms in Google Docs. Among all, only 629 questionnaires were complete in all aspects in both offline and online which were considered for the study. Capital city of Tamil Nadu state was chosen as the study area because large number of service sectors and different cadres and levels of customers were located here.

\subsection{Statistical Design}

With relevance to the research questions and the hypotheses framed, appropriate statistical methods and tools were used in the study to arrive at the findings. Confirmatory Factor Analysis (Structural Equations Model) was also used to analyse the relationship between the effect, sustainability and impact of demonetization on the customer satisfaction. SPSS Version 22 and AMOS Version 20.0 were used for data analysis.

\section{Data analysis and Interpretation}

The model was created with the help of twelve variables such as Approach, Availability, Time, Delivery, Infrastructure, Acceptance, Readiness, Implementation, Adoptability and sustainability and Type of services and versatile payment modes. Type referred as different type of services offered and payment describes the versatile payment mode exhausting the hot cash. Approach is a variable used to demonstrate the way of approach of service providers when "no cash" modes of operations are initiated by the customers. Availability of services during demonetization period when "no cash" is paid by the customers instead they are initiating the digital cash mode. Time of service delivery between the customers categorizing based on cash payment and digital payment was evolved with Time factor. Delivery means the actual service delivery against the digital mode of cash, because some service providers like to discharge the services only against the hot cash rather than the digital cash like electrical cum electronics, repairs and maintenance, spa and saloons and so on. The existence of proper facility for accepting the digital cash at the point of service delivery was defined under Infrastructure. These are exhibited in Fig. 1.

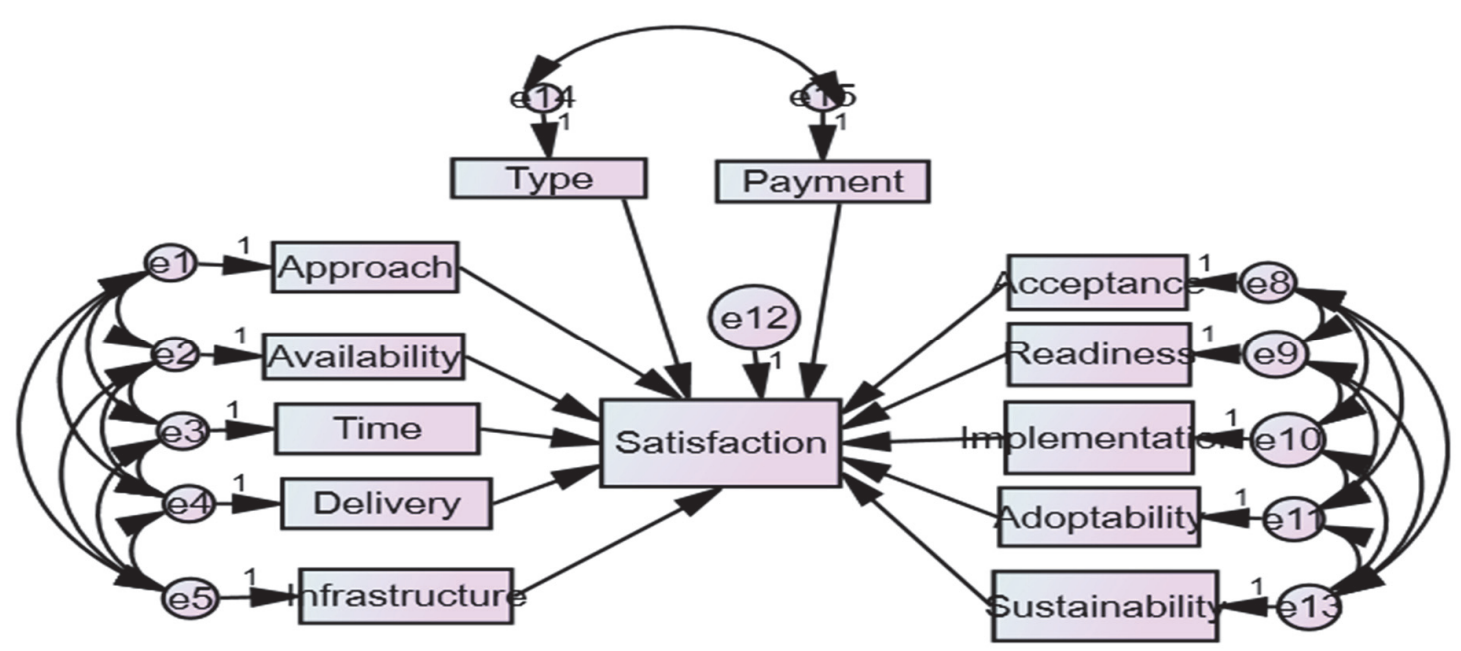

Fig. 1. Measurement model for impact of demonetization on customer satisfaction in service sector

The factor Acceptance was introduced to deliberate the state of acceptance of digital cash by the service provider against the service delivery. Readiness explains the organization of materials and other equipment, labels indicating the process of digital model and instructions cum procedures for accepting the digital cash to the customers. Effective implementation of demonetization and acceptance of digital cash at the point of service delivery was discussed under Implementation. Adoptability of the customers 
towards digital cash and digital payment mode were studied through Adoptability factor. The range of acceptance and application of digital cash for the regular and forthcoming purchases by the customers in all their endeavours were measured through sustainability. The effect of these twelve variables on the satisfaction of the customers has been evolved and the final outcome of each variable on the customers' satisfaction regarding the effect of demonetization in services delivery is shown in the Fig. 2.

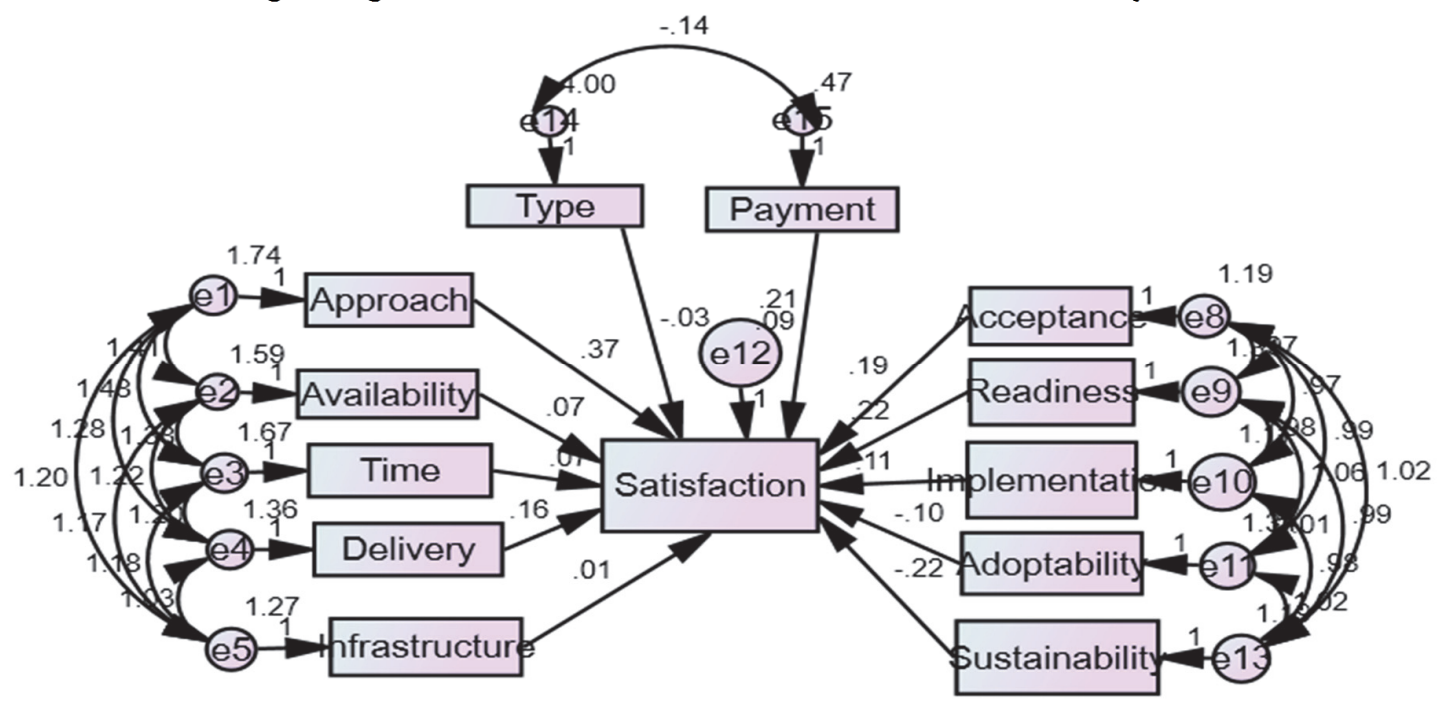

Fig. 2. Measurement model for impact of demonetization on customer satisfaction in service sector with generated output

Fig. 2 exhibits the impact of all the twelve study variables in determining the customers' satisfaction about the service delivery during the phase of demonetization while processing the digital cash mode against the service delivery at the point of services. The measurement model for demonstrating the service delivery and the experience of customers and their derived satisfaction are measured statistically good fit. Table 1 explains the goodness of fit indices for the above measurement model.

\section{Table 1}

Model Fit Summary - Result of confirmatory factor analysis - Measurement model for service sector performance

\begin{tabular}{cccccccc}
\hline Chi square & Df & CMIN/DF & P & GFI & AGFI & CFI & RMSEA \\
\hline 243.918 & 45 & 5.420 & .000 & .808 & .612 & .811 & .253 \\
\hline
\end{tabular}

It was observed from the statistical result of measurement model that, further improvement is suggested and it is necessary to group the factors based on the nature and its salient features. The confirmatory factor analysis explains the goodness of fit indices under three parameter namely GFI, AGFI and CFI, as per the standard expectation of social science research for all these statistical calculation is defined as $>.9$, based on the results all these indices are not fulfilling the expectations. It is decided to go with modification indices and construct the structural model based on the changes recommended by the modification indices. The factors are grouped and the relationship among the variables are streamlined and covariance among the variables are established based on the modification indices in order to sum up the statistical significance of the structural equation model for customer satisfaction on services delivery during demonetization scenario. Fig. 3 depicts the structural equation model for the same with and without the correlation value among the variables included in the study. 


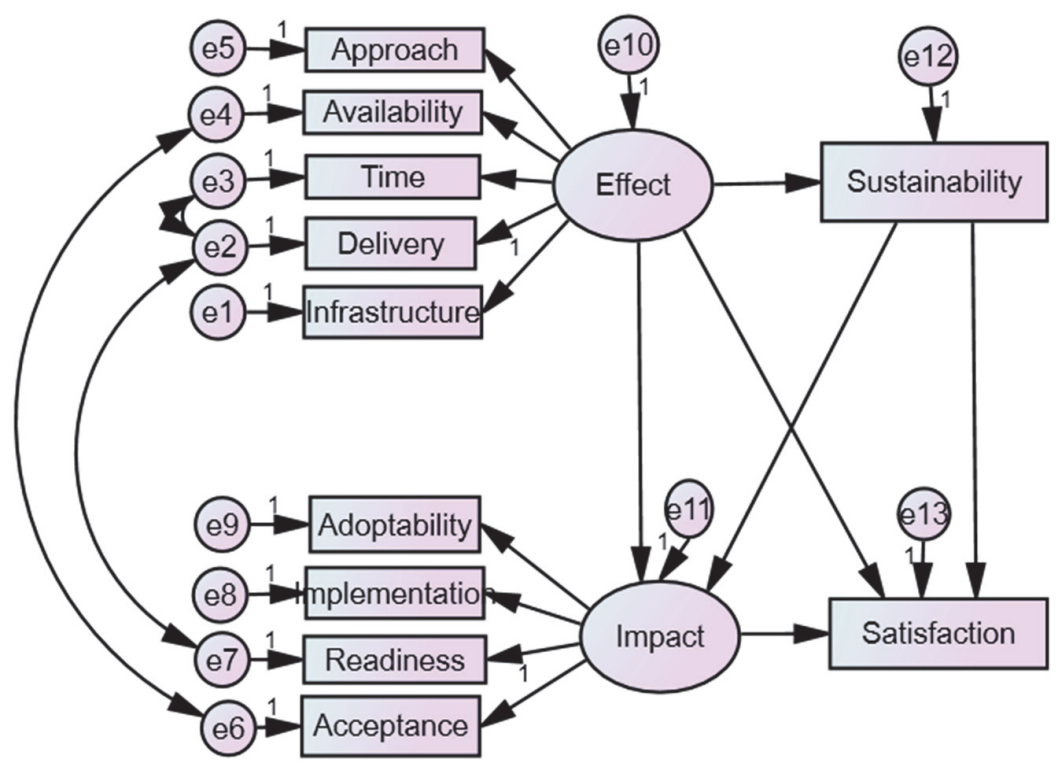

Fig. 3. Structural model for impact of demonetization on customer satisfaction in service sector

According to Fig. 3, we understand that the variables namely Approach, Availability, Time, Delivery and Infrastructure are grouped under Effect category. This group was made with a view to study the service providers approach towards the service offering against the digital cash because all the money collected are accountable directly in their bank accounts, availability of services and service providers to the customers who are making digital payment, the time taken by the service providers against the digital payment customers compared with hot cash payment customers, it is undergone in order to check whether there is any priority in hot cash rather than digital cash. Delivery is the factor brings under Effect, because to evaluate whether there is any default or discrimination in service delivery by the service providers between the customers making hot cash payment and digital cash payment due to demonetization. Finally the arrangement of infrastructure for educating, equipping and encouraging the customers to avail services by paying digital cash at the point of service delivery from the demonetization period also is studied under Effect category.

The impact of the demonetization on the behavioural pattern of both service providers and the customers have been studied through four factors namely Adoptability, Implementation, Readiness and Acceptance. The adoptability of the terms of digital cash by the service providers and the customers have been studied at the point of service delivery. Proper implementations of digital cash at the point of service delivery to certain range of services have not been made properly. The services which are rendered by the organized groups like education services by educational institutions, hospital services, hospitality services, transport services and others have been formulated and designed in a proper way to fulfil the basic norms of principles of demonetization; whereas the services under unorganized services group cannot have all the facilities to design and implement all the formalities required at the time of demonetization. Thus, based on the services the availability of infrastructure is varied and needs to be studied in deep under the impact of demonetization. The factors readiness and acceptance are included in the study to test the readiness of the mind-set of the people to avail the digital payment and digital cash mode. The acceptance factor was evolved under different stages that is before, during and after the demonetization. The effect of the variables like Approach, Availability, Time, Delivery and Infrastructure required availing the digital cash at the point of service delivery under the effect group and its relationship with sustainability was focussed in order to know whether these effects continue even after the vigorous application of demonetization concept in India. The effect of these variables, 
the sustainability in applying and continuing the effect of these variables on the impact of demonetization have been analysed further. The structural model shown in Fig. 4 again attempts to deliberate the relationship between the effect, sustainability and impact on the customer satisfaction. The structural model which is created using AMOS v.21 has been employed to define the relationship between the effect, sustainability, impact and ultimately the customer satisfaction. The confirmatory factor analysis has been used to evaluate the structural relationship, since the variables were observed and well defined by the researchers for conducting the study and the statistical results have proven that the model for customer satisfaction on service delivery during and after demonetization based on the study variables were statistically significant and it explained the best statistical results with standardized goodness of fit indices at the required and standard level. Fig. 4 and Table 2 exhibit the statistical relationship among the variables used to build the structural equation model. Under confirmatory factor analysis, it results with numerous statistical values, for this study only the goodness of fit indices and RMSEA and RMR were considered to test the significance of the derived model.

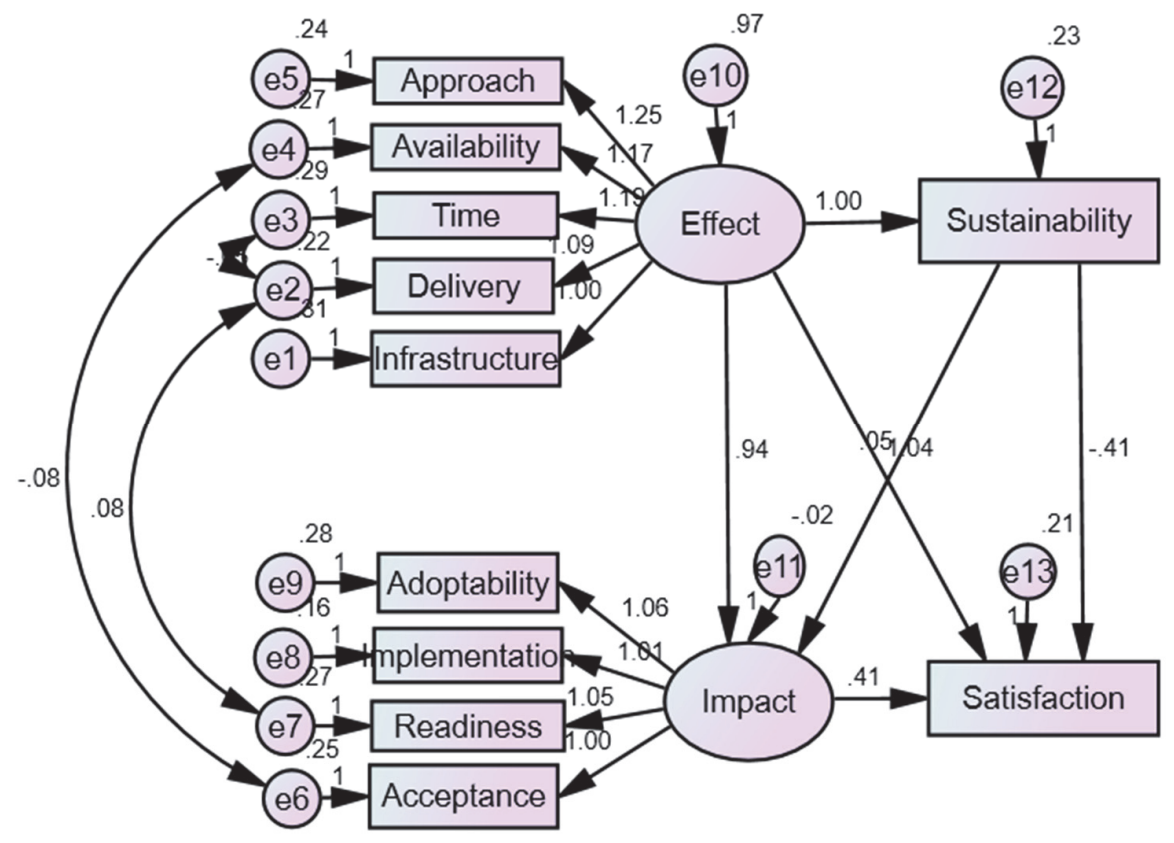

Fig. 4. Structural model for impact of demonetization on customer satisfaction in service sector with generated output

Table 2

Result of confirmatory factor analysis - Structural model for service sector performance

\begin{tabular}{ccccccccc}
\hline Chi square & Df & CMIN/DF & p & GFI & AGFI & CFI & RMSEA & RMR \\
\hline 38.725 & 37 & 1.047 & .000 & .909 & .837 & .998 & .026 & .024 \\
\hline
\end{tabular}

From the confirmatory factor analysis in Table 2, the Chi-Square result found very low and the P-value is significant. It is considered the defined structural model was best fit. Further the Goodness of fit indices like GFI, Adjusted GFI and CFI were also at satisfactory level. The Root Mean Square Error Approximation (RMSEA) results with .026 and the RMR also shows only .024, minimal the value, the best the model is. Hence as per the standard requirement the constructed structural equation model for customer satisfaction on service delivery during after demonetization is best fit. The regression weight for the following observed, endogenous variables such as Infrastructure, Delivery, Time, Availability, Approach, Acceptance, Readiness, Implementation, Adoptability, Sustainability and Satisfaction; and the Unobserved, endogenous variables such as Effect and Impact are provided in the Table 3. It was observed that, the regression weight expresses significant relationship among all the five endogenous variables to Effect and all the four endogenous variables to Impact. Hence, defining and grouping these 
endogenous variables under these two unobserved variables such as effect and impact are gained statistically significance. Further, the effect on Impact for demonetization on service delivery and the sustainability of using the digital cash shows statistically significant relationship, whereas the relationship between the sustainability and impact are not statistically significant, it explains that if the people do not follow the adoption of digital cash provisions for the consecutive period to maintain its sustainability, then the impact on services sector is not significantly registered. Finally the contribution of effect, impact and sustainability towards the customer satisfaction is studied. It deliberately explains that, neither the variables under Effect category nor the factors under 'Impact' category had significant contribution towards gaining the customers' satisfaction. It is well established that only by means of achieving the sustainability in adopting the demonetization effect and its impact on digital cash procedures will have notorious impression in the customers' behaviour and pave a way to reach the best customer satisfaction as outcome.

Table 3

Regression Weights

\begin{tabular}{|c|c|c|c|c|c|c|c|c|}
\hline Variables & & & Unstd Estimate & Std Estimate & S.E. & C.R. & $P$ & Result \\
\hline Sustainability & $\leftarrow$ & Effect & .999 & .900 & .091 & 11.033 & $* * *$ & Significant \\
\hline Impact & $\leftarrow$ & Sustainability & .052 & .059 & .070 & .741 & .459 & Insignificant \\
\hline Impact & $\leftarrow$ & Effect & .942 & .958 & .114 & 8.273 & $* * *$ & Significant \\
\hline Infrastructure & $\leftarrow$ & Effect & 1.000 & .872 & & & & \\
\hline Delivery & $\leftarrow$ & Effect & 1.086 & .916 & .094 & 11.548 & $* * *$ & Significant \\
\hline Time & $\leftarrow$ & Effect & 1.193 & .908 & .105 & 11.335 & $* * *$ & Significant \\
\hline Availability & $\leftarrow$ & Effect & 1.167 & .910 & .102 & 11.385 & $* * *$ & Significant \\
\hline Approach & $\leftarrow$ & Effect & 1.248 & .930 & .104 & 11.994 & $* * *$ & Significant \\
\hline Acceptance & $\leftarrow$ & Impact & 1.000 & .887 & & & & \\
\hline Readiness & $\leftarrow$ & Impact & 1.055 & .892 & .093 & 11.381 & $* * *$ & Significant \\
\hline Implementation & $\leftarrow$ & Impact & 1.007 & .926 & .080 & 12.539 & $* * *$ & Significant \\
\hline Adoptability & $\leftarrow$ & Impact & 1.062 & .889 & .094 & 11.332 & $* * *$ & Significant \\
\hline Satisfaction & $\leftarrow$ & Impact & .407 & .348 & .734 & .554 & .580 & Insignificant \\
\hline Satisfaction & $\leftarrow$ & Effect & 1.043 & .907 & .665 & 1.567 & .117 & Insignificant \\
\hline Satisfaction & $\leftarrow$ & Sustainability & -.412 & -.398 & .155 & -2.666 & .008 & Significant \\
\hline
\end{tabular}

The hypotheses which are defined for constructing the model was tested for statistical significance under Confirmatory factor analysis. Table 4 describes the hypotheses and its acceptance and rejection criteria based on their statistical relevance. The hypotheses are constructed based on the prominent variables used for constructing the model such as effect, impact, sustainability and the derived customer satisfaction. The entire model is focussed on customer satisfaction as the outcome and all the other factors are considered as the designing and constructing variables.

Table 4

Hypothesis testing

\begin{tabular}{cllcc} 
Variable 1 & Variable 2 & \multicolumn{1}{c}{ Hypothesis } & P Value & Result \\
Satisfaction & Impact & $\begin{array}{l}\text { Impact of demonetization does not influence customer sat- } \\
\text { isfaction }\end{array}$ & .580 & Not Rejected \\
Satisfaction & Effect & $\begin{array}{l}\text { Effect of demonetization does not influence customer sat- } \\
\text { isfaction }\end{array}$ & .117 & Not Rejected \\
Satisfaction & Sustainability & Sustainability does not influence customer satisfaction & .008 & Rejected \\
\hline
\end{tabular}

\section{Conclusion and Recommendation}

It was concluded that, the structural equation model explains the impact of demonetization based on Adoptability, Implementation, Readiness and Acceptance of new payment methods and digital cash against the service delivery at the point of services delivery both by the services providers and the customers over the period of time after the proper implementation of demonetization was significant influencing the customer satisfaction under service sector. It means that improvement under payment method will bring the easiness and convenience in discharging the payment and other procedures very 
simple, so it attracts both the end of services delivery more and it further leads to customer satisfaction ultimately. Next, the effects of factors like Approach, Availability, Time, Delivery and Infrastructure had significant contribution towards the customers' satisfaction. The easy approachability towards service providers and availability of payment mode through digital cash, proper infrastructure, readiness stage at both the ends of service delivery towards making digital payment, and establishment of proper infrastructure facility to proceed with digital cash, awareness, familiarity and knowledge about the execution of payment mode through digital cash plays significant role in determining the improved satisfaction level of the customers.

It is very hard to accept and adjudicate any practices once it is implemented, it will take its own time and place to gain familiarity among the customers and the service providers. Even though it is mandatory from the government point of view to utilize the digital payment mode to reduce the currency transactions and erode the black money concept. Thus, the general public are convinced themselves and started to adopt the digital cash practices even if they are not feeling comfortable at the initial stage. But later on, the ease of operations and compatibility help the people understand its importance and proceed to adopt the technology revolution like the mobile phone penetration. From the study, it was identified that both the effect of demonetization to prepare the people to utilize the digital cash mode at the point of service delivery and also the impact of demonetization would not influence much on the customer satisfaction even after one year period of demonetization revolution. In order to give vigilance towards Anti-money laundry, black money restriction and economic well-being, government has to take much initiative to penetrate the digital cash even among the rural poor. Further, the study reveals that sustainability in operations of demonetization, its benefits and improved security mechanisms will bring more customer satisfaction than ever. Hence it is required by the part of government to improve the method of delivery of service connected to payment apps and other e-wallets, its operations under multi-linguistic platform, the improved security mechanisms and active remedial measures and grievance mechanisms will result with much attraction over the period of time. The close supervision and strict adherence of security concern again build satisfactory infrastructure to the customer and real beneficiaries who make use of these digital cash mechanisms. There is no evidence and regulatory norms to strictly adhere the digital cash payment always at the point of service delivery, again there is no statutory provisions to follow only the digital cash payment. It is completely made the customers and service providers feel freehand to use the hot cash rather than the digital cash mode transactions. To have sustainability in usage of digital cash payment system and enjoy the fruitiness of demonetization in service sectors, it is expected a minimum law and provision insisting to make payment digitally against the services which are initiated and rendered from the government organizations and organized service sector institutions.

\section{Practical Implications}

The taste of fruit cannot be enjoyed and nutrient on the same day of the seedling, but continuous care is required to grow as tree and yield us the benefits. It was argued and evidenced from many historical innovations and inventions that the success of any technological upgradations and transformations lies only with continuous, substantial and effective applications of it in a wide range by the society. If the transformations in any work were not efficiently implemented and effectively monitored, then its achievement would be less measurable. Much effort is needed to implement continuously, hence it is demanded a special and unique legal enforcement to make the monetary transactions in digital mode not in adhoc manner but signing permanently, at least in government organizations and organized service sectors related transactions.

\section{Acknowledgement}

The authors would like to thank the anonymous referees for constructive comments on earlier version of this paper. 


\section{References}

Adhikary, A., \& Bora, B. (2017). Demonetization: A case in Indian perspective. International Journal of Economic Behavior and Organization, 5(3), 80-86.

Chopra, R. (2017). Impact of demonetization on Indian economy. Global Journal of Enterprise Information System, 9(2). [online] https://doi.org/10.18311/gjeis/2017/15857

Enara, A., \& Gowda, M. R. (2018). The enigma of demonetization and the unexplored consequences. Indian Journal of Psychiatry, 60(1), 6-9.

Kumar, S., \& Bumra, M. S. (2017). Demonetization in India: Pre and post effect on Indian industry. International Journal of Scientific \& Engineering Research Volume, 8(7), 266-274.

Kaur, J. (2017). Impact of demonetization on Indian economy. South Asian Journal of Marketing \& Management Research, 7(6), 53-57.

Kushwaha, H., Kumar, A., \& Abbas, Z. (2018). Impact of demonetisation on Indian economy: A critical study. International Journal of Management Studies, 2(7), 25-31. DOI:10.18843/ijms/v5i2(7)/04.

IndiaToday (2017, November 9). India after one year of demonetization: Where do we stand?, IndiaToday.in, New Delhi. https:/www.indiatoday.in/education-today/gk-current-affairs/story/oneyear-since-demonetisation-note-ban-1082049-2017-11-08.

Midthanpally, R. S. (2017). Demonetisation and remonetisation in India: State-induced chaos or responsible governance?, South Asia Research, 37(2), 213-227.

Nag, A.K. (2016). Lost due to demonetisation. Economic \& Political Weekly, 51(48), 18-21.

Santani, P. (2018). Demonetisation (Demonetization): Essay, Speech, Article, Short Note, Paragraph, [online] http://www.myeducorner.com/demonetisation-demonetization-essay-speech-article-noteparagraph/ (Accepted on February 15, 2018).

Santoshi, I. (2017). Constitutional validity of demonetization in India. International Journal of Law, $3(1), 45-47$.

Shaikh, A., \& Deshpande, S. (2017). Demonetization and its impact on Indian economy- A Review. International Journal of Advances in Management and Economics, 6(5), 12-20.

Special Correspondent, (2016, November 12). As ATMs run out of cash, RBI 'encourages' public to go digital. The Hindu, https://www.thehindu.com/business/Economy/As-ATMs-run-out-of-cashRBI-\%E2\%80\%98encourages\%E2\%80\%99-public-to-go-digital/article16444418.ece (Accepted on November 1, 2018).

Uke, L. (2017). Demonetization and its effects in India. SSRG International Journal of Economics and Management Studies, 4(2), 18-23.

Upadhyay, D., \& Suvarna, S. W. (2018). Impact of demonetization on the Indian stock market: With special reference to Bombay Stock Exchange, Paradigm, 22(2), 175-184.

Tax Research Team (2016, November 14). Demonetisation: Impact on the economy. National Institute of Public Finance and Policy, New Delhi, No. 182.

The Bureau, (2017, September 08). One year into demonetisation: Here is a report card of what worked, what didn't. The Economic Times

[online] https://economictimes.indiatimes.com/news/politics-and-nation/one-year-into-demonetisation-here-is-a-report-card-of-what-worked-what-didnt/articleshow/61553072.cms (Accepted on Nov 08, 2017).

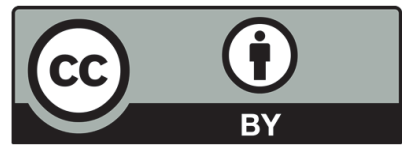

(C) 2019 by the authors; licensee Growing Science, Canada. This is an open access article distributed under the terms and conditions of the Creative Commons Attribution (CC-BY) license (http://creativecommons.org/licenses/by/4.0/). 